\title{
Efficacy of the Methanolic and Aqueous Extracts of Carica Papaya and Azadirachta Indica against Wood Termite (Odontotermes Badius) in Uyo, Akwa Ibom State, Nigeria
}

\author{
Akpan A. U. ${ }^{1 *}$, Ehisianya C. N. ${ }^{2}$, Ukpai O. M. ${ }^{3}$, Johnny I. I. ${ }^{4}$, Oboho D. E. ${ }^{5}$, \\ Sam M. E. ${ }^{6}$ and Usanga E. E. ${ }^{7}$ \\ ${ }^{1,5,6,7}$ Department of Animal and Environmental Biology, University of Uyo, Akwa Ibom State, Nigeria \\ ${ }^{2,3}$ Department of Zoology and Environmental Biology, Michael Okpara University, Umudike, Abia State, \\ Nigeria \\ ${ }^{4}$ Pharmacognosy and Natural Medicine, Faculty of Pharmacy, University of Uyo, Akwa Ibom State, Nigeria \\ Corresponding Author:*akpanudoh@uniuyo.edu.ng
}

https://doi.org/10.36263/nijest.2022.01.0306

\begin{abstract}
Evaluation of the efficacy of methanolic and aqueous extracts of Carica papaya and Azadirachta indica against the wood termite (Odontotermes badius) was carried out in the Botany garden, University of Uyo main campus, Akwa Ibom State. The phytochemical properties of the extracts were carried out in the Department of Pharmacognosy and Natural Medicine, Faculty of Pharmacy, University of Uyo, Akwa Ibom State, using the standard procedures. The untreated wood (Ceiba pentandra) was cut into 60 pieces of equal sizes of $11 \mathrm{~cm} x 8 \mathrm{~cm}$. $40 \mathrm{ml}$ and $80 \mathrm{ml}$ concentrations (Using 100ml unit syringe) of each of the extracts of the leaves and stem parts of $C$. papaya and A. indica were applied on the woods using soft-faced brush. The control treated with water. The treated woods well labeled using a marker. The treated woods and the control were inserted horizontally into the termitarium and were monitored for 24, 48, 72 and 96 hours. The data collected were analyzed using two way Analysis of Variance (ANOVA), and their means separated using $p<0.05$ probability. The phytochemical screening results of aqueous and methanolic extract of $C$. papaya and A. indica indicated the presence of flavonoids, saponins, tannins, terpernoids, phenols, cardiac glycosides, alkaloids and anthraquinine. The results showed that the methanolic plant extracts of $C$. papaya and A. indica leaves and stem offered greater effectiveness for wood protection against termite (O. badius) compared to the aqueous extracts of the plants.
\end{abstract}

Keywords: Extracts, Aqueous, Carica papaya, Azadirachta indica, Odontotermes badius

\subsection{Introduction}

Wood is one of the oldest known materials used in the construction of structures with a wide variety of application (Tolunay et al., 2008). Woods are used in different environmental conditions and are subject to biodegradation and deterioration but when properly preserved, it has the ability to withstand these conditions for many years (Sotannde et al., 2011). One of the major agents of degradation of wood is termite attack (Obomanu et al., 2011).

Chemicals such as Solignum and Thiamethoxam have been generally used to providing a longer protection of wooden materials from termites' infestation but due to their environmental hazard and residual effect on non-target and ecofriendly organisms the usage of such chemicals is reducing and getting them is becoming difficult while the use of biopesticides from plants have been highly and strongly advocated for (Oyedokun et al., 2011; Silva et al., 2012; Céspedes et al., 2014; Ugbomeh and Diboyesuku, 2019; Ubulom et al., 2020). This is gaining importance. 
Over the years, efforts have been channeled by different researchers to finding alternative sources of materials for the preservation of wooden materials from attack by the termites. These alternative sources use extracts from different tropic plants which are environmentally friendly and are normally perceived as having less potential damage to non-target organisms (Oyedokun et al., 2011). Wood preservatives available in tropical flora are gradually replacing their chemical counterparts especially in developing countries.

Biopesticides from plants usually degrade in a short period of time which make them ecofriendly and safer for the environment. Plants possess secondary metabolites which are active and even interfere in the life processes of pest(s) (Adeyemi, 2010).

Termites are social insects living in colonies and they belong to the order Isoptera (Grimaldi and Engel, 2005). They are distributed in the tropical and subtropical regions of the world (Hassan et al., 2017). Termites are one of the most damaging pests in the tropics and cause considerable problems in housing, agriculture and forestry (Ahmed et al., 2016). Termite community present great species diversity with various types of feeding and nesting places (Akpan et al., 2020). Termites are herbivores, fungivores and humivores. They feed on cellulose, directly from plants, dead or alive, or indirectly from fungus arising from decaying plant material with mounds (Resh and Carde, 2003). Odontotermes badius constitute over $90 \%$ of the termite species and it is very beneficial to the ecosystem balance as agent of decomposition in the soil (Eggleton, 2007; Ajao et al., 2018; Chiu et al., 2018). It is also known to cause great damage to wood structure in homes as a result of its wood diet and other cellulose materials (Picker, 2004; Chiu et al., 2018) and are agricultural pests in the tropics and subtropics of Africa and Asia (Chiu et al., 2018).

In the main campus of University of Uyo, the pest activities of termites has been on the increase, ranging from infesting woods so much that it has caused serious damages to buildings particularly in Faculty of Science and the Administrative block, to reducing of farmlands via building of termitaria, hence the need for this study. Carica papaya and Azadirachta indica were chosen for this study. They are known to possess numerous metabolites that are bioactive (Arambewela et al. (2005). Also, the choice of the aqueous solvent with methanolic solvent, for the preparation of $C$. papaya and A. indica extracts was informed by the fact that different solvents give different concentrations of essential oils due to their differences in polarity indices (Nimmi et al., 2012), and biopesticides must be affordable and simple to prepare (Isman, 2017).

Considering the enormous reports on the promising nature of biopesticides obtained from plants against termites in the tropics in controlled environment, the objective of this study was to examine the efficacy of methanolic and aqueous extracts of $C$. papaya and A. indica against wood termite (Odontotermes badius) in the field.

\subsection{Methodology}

\subsection{Study area}

The field work was carried out between July 2019 and October 2019 in the Botany garden, University of Uyo Main campus, Uyo Akwa Ibom State. The termitaria were located close to the ultramodern hostel and surrounded by plant such as Cassava (Manihot esculenta), Spear grass (Heteropogon contortus), Awolowo plant (Chromolaena odorata), Fern (Polypodium glycyrrhiza). The termite identification was done by an Entomologist in the Entomology unit, Department of Animal and Environmental Biology using the keys provided by Arif et al. (2019).

\subsubsection{Plant collection and identification}

The leaves and stems of C. papaya (pawpaw) and A.indica (neem) were collected in Mbiaobong Etoi, Uyo Local Government Area, Akwa Ibom State. The plants were identified by a Curator, Department of Botany and Ecological studies, University of Uyo.

\subsubsection{Source of wood}


The wood, African nutmeg; Ceiba pentandra (Local name: Ukim) was sourced from timber market at Ifa Ikot Okpon in Mbiaobong Etoi, Uyo, Akwa Ibom State.

\subsubsection{Preparation of plant extracts}

The leaves and stems collected were chopped and sun dried after which they were ground to powder using mortar and pestle. The pulverized samples were kept in air tight containers and stored at room temperature (Selase and Getu, 2009; Addisu et al., 2014; Ojianwuna et al., 2016). Dried plant material weighing $700 \mathrm{~g}$ for both stem and leaves each was measured and macerated with water for 24 hours for the aqueous extract while quantity $(700 \mathrm{~g})$ of the plant materials was macerated and allowed to stay for 72 hours (done for stem and leaves). Filtration was done using cotton wool and the filtrate was concentrated to dryness at $45^{\circ} \mathrm{C}$. The dried extract was then preserved in the fridge at $-4^{\circ} \mathrm{C}$ prior to use (Selase and Getu, 2009).

\subsubsection{Phytochemical screening}

Phytochemical screening was carried out in the Department of Pharmacognosy and Natural Medicine, Faculty of Pharmacy, University of Uyo, Akwa Ibom State, using the standard procedures as described by Evans (2002), Adegoke and Bukola (2009) and Prashant et al. (2011) with slight modification. The following qualitative metabolite tests were done:

\subsubsection{Test for Alkaloids}

From the extracts, 0.2 gram was warmed with $2 \%$ of $\mathrm{H}_{2} \mathrm{SO}_{4}$ for two minutes, then filtered. Two drops of Dragendoff's reagent were added. Orange red precipitate with turbidity indicates the presence of alkaloids.

\subsubsection{Test for Phenols}

Two milliliter $(2 \mathrm{ml})$ of $2 \%$ solution of $\mathrm{FeCl} 3$ mixed with crude extract. Black or blue-green color indicated the presence of phenol.

\subsubsection{Test for Saponin}

One milliliter ( $\mathrm{I} \mathrm{ml}$ ) of each plant extract were diluted with $2 \mathrm{ml}$ of distilled water; the mixture were vigorously shaken and left to stand for 10 mins during which time, the development of foam on the surface of the mixture lasting for more than 10 mins, indicates the presence of Saponins.

\subsubsection{Test for Anthraquinones}

One milliliter $(\mathrm{Iml})$ of the plant filtrate were shaken with $10 \mathrm{~mL}$ of benzene; the mixture was filtered and $5 \mathrm{ml}$ of $10 \%(\mathrm{v} / \mathrm{v})$ ammonia were added, then shaken and observed. A pinkish solution indicates a positive test.

\subsubsection{Test for Flavonoid}

One milliliter ( $\mathrm{Iml}$ ) of plant filtrate were mixed with $2 \mathrm{~mL}$ of $10 \%$ lead acetate; a brownish precipitate indicated a positive test for the phenolic flavonoids. While for flavonoids, $1 \mathrm{ml}$ of the plant filtrate were mixed with $1 \%$ ammonia solution; a golden yellow colour indicated the presence of flavonoids (Ade-Ajayi et al., 2011).

\subsubsection{Test for Cardiac Glycosides}

Salkowski's Test (for steroidal ring):

Plant extract $(0.5 \mathrm{~g})$ was dissolved in $2 \mathrm{ml}$ of chloroform. Concentrated tetraoxosulphate (vi) acid was carefully added by running it down the side of the test tube. A reddish brown colour at the interphase indicated the presence of a glycone portion of cardiac glycosides.

\subsection{Wood treatment}

The untreated wood was cut according to procedures from Okere et al. (2021) with modifications, into 60 pieces of equal size of $11 \mathrm{~cm} \times 8 \mathrm{~cm}$. They were differentiated using a marker. The cut pieces of wood were treated with $40 \mathrm{ml}$ and $80 \mathrm{ml}$ concentrations (measured using $100 \mathrm{ml}$ unit syringe) of each of the extracts of the parts of the plants using small soft-faced brush. The treated pieces of wood were 
left to air- dry for 24 hours. The control was treated with water. The treated pieces of wood with the plant extracts together with the control were placed in a pan and transported to site. The termitaia were dug using a spade. The treated pieces of woods and the control were inserted horizontally into the termitaria and covered with leaves. They were checked for termites attack at interval of 24, 48, 72 and 96 hours.

\subsection{Repellency test}

The repellency activity on the pieces of wood against the termite was measured using the following formula (Equation 1) (Osipitan et al., 2013), with modification.

$R=\frac{T c-T a}{T c}$

where

$\mathrm{R}=$ Repellency

$\mathrm{Tc}=$ Number of termite indicated by the cast built on wood

$\mathrm{Ta}=$ Termites counted around the wood without attacking

Modification: The number of termite repelled from attacking the wood was determined by the number of the termites' effect on the wood that is the observed built up termite cast on the woods, and the result not multiplied by 100 .

\subsection{Mortality test}

The mortality test in the field was carried out by observing the behaviour of the termites after close contact to the treated pieces of wood (Osipitan and Oseyemi, 2012).

\subsubsection{Statistical analysis}

Data obtained were entered n Microsoft Excel version 2013. Descriptive statistics (mean, standard error) were calculated for the treatment. Two way Analysis of Variance (ANOVA) was performed and the level of significance was measured using Student-Newman-Keuls Test at $p<0.005$.

\subsection{Results and Discussion}

\subsection{Phytochemical composition of the leave and stem parts of the extracts of the two plants.}

The results of the phytochemical screening of the leaves and stems of $C$. papaya and A. indica using methanol and aqueous media indicate that alkaloid and saponins were present in the methanolic and aqueous extracts of the parts of the two plants, while terpenoid was only present in the methanolic extract of the leaves and stem of A. indica (neem) (Table 1).

Table1: Phytochemical screening of both leaves and stems of $C$. papaya and A. indica

\begin{tabular}{llllllllll}
\hline \multirow{2}{*}{ EXTRACT COMPONENT } & \multicolumn{3}{l}{ METHANOLIC EXTRACT } & \multicolumn{5}{c}{ AQUEOUS EXTRACT } \\
\cline { 2 - 10 } & \multicolumn{3}{l}{ C. papaya } & \multicolumn{3}{l}{ A. indica } & \multicolumn{4}{c}{ C. papaya } & A. indica \\
\cline { 2 - 10 } & Leaves & Stem & Leaves & Stem & Leaves & Stem & Leaves & Stem \\
\hline Alkaloid & + & + & + & + & + & + & + & + & + \\
Terpenoid & - & - & + & + & - & - & - & - \\
Tannins & + & + & + & + & - & + & + & + \\
Phenols & + & + & + & - & - & + & + & + \\
Saponins & + & + & + & + & + & + & + & + \\
Flavonoids & + & - & + & + & + & + & + & + \\
Anthraquinone & - & - & + & + & + & + & + & - \\
Cardiacglycoside & + & + & + & + & + & + & + & - \\
\hline
\end{tabular}

The results obtained from this research study indicates that plant extracts could be effective in the control of the pest effect of termites on stored products such as woods, even due highly effective chemical substances have been available for many years to prevent the pest effect of termites on wood (Ahmed et al., 2016). 
According to Obinna et al. (2013) the effectiveness of any plant extract mainly depends on concentrations and types of extraction solvents, which in this study methanol and aqueous solutions were used as solvents, and from the phytochemical screening of $C$. papaya the result revealed the presence of alkaloids, tannins, phenols, saponins, flavonoids and cardiac glycoside which corresponds with Noorshilawati et al. (2016) and that of A. indica indicated the presence of alkaloids, terpenoids, tannins, phenols, saponins flavonoids and cardiac glycoside which agrees with Biu et al. (2009).

\subsection{The efficacy of the extracts of the plants parts against termite}

Methanolic Leave Pawpaw (MLP) and Methanolic Stem Neem (MSN) treatment at concentration of $80 \mathrm{ml}$ were more effective with no attack observed on the wood throughout the durations of testing (Table 2) while results from MSP and MSN treatments on the wood at concentration $40 \mathrm{ml}$ and $80 \mathrm{ml}$ respectively effectively repelled the termites without observing any attack on the wood (Table 3 ). The comparison of aqueous extract of the parts of $C$. papaya (pawpaw) revealed no significant difference $(\mathrm{p}>0.05)$ during the period of exposure after 24 hours (5.67), 48 hours (7.17), 72 hours (7.92) and 96 hours (8.50) (Figure 1).

Table 2: Mean ( \pm Standard error) of mortality of termite infesting woods treated with the two plant extracts in Akwa Ibom State

\begin{tabular}{llcccc}
\hline Dosage $(\mathrm{ml})$ & Treatment & \multicolumn{4}{c}{ Duration (Hours) } \\
\cline { 3 - 6 } & & 24 & 48 & 72 & 96 \\
\hline $40 \mathrm{ml}$ & ALN & $0.00^{\mathrm{b}} \pm 0.00$ & $0.00^{\mathrm{a}} \pm 0.00$ & $0.00^{\mathrm{b}} \pm 0.00$ & $0.00^{\mathrm{b}} \pm 0.00$ \\
$80 \mathrm{ml}$ & ALP & $0.33^{\mathrm{b}} \pm 0.33$ & $0.00^{\mathrm{a}} \pm 0.00$ & $0.00^{\mathrm{b}} \pm 0.00$ & $0.00^{\mathrm{b}} \pm 0.00$ \\
$40 \mathrm{ml}$ & ASN & $8.33^{\mathrm{b}} \pm 8.33$ & $9.33^{\mathrm{a}} \pm 9.33$ & $11.00^{\mathrm{b}} \pm 11.00$ & $11.00^{\mathrm{b}} \pm 11.00$ \\
$80 \mathrm{ml}$ & ASP & $0.00^{\mathrm{b}} \pm 0.00$ & $0.33^{\mathrm{a}} \pm 0.33$ & $0.00^{\mathrm{b}} \pm 0.00$ & $0.00^{\mathrm{b}} \pm 0.00$ \\
$40 \mathrm{ml}$ & MLN & $0.00^{\mathrm{b}} \pm 0.00$ & $0.00^{\mathrm{a}} \pm 0.00$ & $1.33^{\mathrm{b}} \pm 1.33$ & $0.00^{\mathrm{b}} \pm 0.00$ \\
$80 \mathrm{ml}$ & MLP & $0.00^{\mathrm{b}} \pm 0.00$ & $0.00^{\mathrm{a}} \pm 0.00$ & $0.00^{\mathrm{b}} \pm 0.00$ & $0.00^{\mathrm{b}} \pm 0.00$ \\
$40 \mathrm{ml}$ & MSP & $0 . .00^{\mathrm{b}} \pm 0.00$ & $0.33^{\mathrm{a}} \pm 0.33$ & $0.00^{\mathrm{b}} \pm 0.00$ & $0.00^{\mathrm{b}} \pm 0.00$ \\
$80 \mathrm{ml}$ & MSN & $0.00^{\mathrm{b}} \pm 0.00$ & $0.00^{\mathrm{a}} \pm 0.00$ & $0.00^{\mathrm{b}} \pm 0.00$ & $0.00^{\mathrm{b}} \pm 0.00$ \\
& CONTROL (Water) & $29.67^{\mathrm{a}} \pm 7.98$ & $22.67^{\mathrm{a}} \pm 7.88$ & $40.67^{\mathrm{a}} \pm 6.58$ & $38.67^{\mathrm{a}} \pm 9.10$ \\
\hline
\end{tabular}

Means with the same letters $(a, b, c)$ are not significantly different. ALN = Aqueous Leave Neem; ALP=Aqueous Leave Pawpaw; ASN=Aqueous Stem Neem; ASP=Aqueous Stem Pawpaw; MLN=Methanolic Leave Neem; MLP= Methanolic Leave Pawpaw; $M S P=$ Methanolic Stem Pawpaw; MSN= Methanolic Stem Neem.

Table 3: Mean ( \pm Standard Error) repellency of woods treated with the two plant extracts against termite in Akwa Ibom State

\begin{tabular}{llcccc}
\hline Dosage & Treatment & \multicolumn{4}{c}{ Duration (hours) } \\
\cline { 3 - 6 } & & 24 & 48 & 72 & 96 \\
\hline $40 \mathrm{ml}$ & ALN & $18.03^{\mathrm{ab}} \pm 3.67^{\mathrm{ab}}$ & $18.33^{\mathrm{a}} \pm 6.12$ & $22.00^{\mathrm{ab}} \pm 5.03$ & $26.33^{\mathrm{a}} \pm 5.78$ \\
$80 \mathrm{ml}$ & ALP & $4.00^{\mathrm{a}} \pm 4.00$ & $7.33^{\mathrm{bc}} \pm 4.33$ & $9.67^{\mathrm{ab}} \pm 5.24$ \\
$40 \mathrm{ml}$ & ASN & $15.00^{\mathrm{ab}} \pm 2.08$ & $19.67^{\mathrm{a}} \pm 2.60$ & $21.00^{\mathrm{ab}} \pm 3.00$ & $21.67^{\mathrm{ab}^{\mathrm{b}} \pm 3.38}$ \\
$80 \mathrm{ml}$ & ASP & $2.67^{\mathrm{b}} \pm 2.67$ & $0.00^{\mathrm{a}} \pm 0.00$ & $4.33^{\mathrm{c}} \pm 4.33$ & $6.33^{\mathrm{ab}} \pm 4.48$ \\
$40 \mathrm{ml}$ & MLN & $1.67^{\mathrm{b}} \pm 1.67$ & $3.33^{\mathrm{a}} \pm 3.33$ & $5.33^{\mathrm{c}} \pm 5.33$ & $5.00^{\mathrm{ab}} \pm 5.00$ \\
$80 \mathrm{ml}$ & MLP & $1.67^{\mathrm{b}} \pm 1.67$ & $0.00^{\mathrm{a}} \pm 0.00$ & $0.00^{\mathrm{c}} \pm 0.00$ & $6.00^{\mathrm{ab}} \pm 6.00$ \\
$40 \mathrm{ml}$ & MSP & $0.00^{\mathrm{b}} \pm 0.00$ & $0.00^{\mathrm{a}} \pm 0.00$ & $0.00^{\mathrm{c}} \pm 0.00$ & $0.00^{\mathrm{b}} \pm 0.00$ \\
$80 \mathrm{ml}$ & MSN & $0.00^{\mathrm{b}} \pm 0.00$ & $0.00^{\mathrm{a}} \pm 0.00$ & $0.00^{\mathrm{c}} \pm 0.00$ & $0.00^{\mathrm{b}} \pm 0.00$ \\
& CONTROL (Water) & $28.17^{\mathrm{a}} \pm 7.67$ & $19.67^{\mathrm{a}} \pm 4.94$ & $28.17^{\mathrm{a}} \pm 4.26$ & $28.33^{\mathrm{a}} \pm 5.72$ \\
\hline
\end{tabular}

Means with the same letters $(a, b, c)$ are not significantly different. ALN = Aqueous Leave Neem; ALP = Aqueous Leave Pawpaw; ASN= Aqueous Stem Neem; ASP=Aqueous Stem Pawpaw; MLN=Methanolic Leave Neem; MLP= Methanolic Leave Pawpaw; MSP= Methanolic Stem Pawpaw; MSN= Methanolic Stem Neem. 


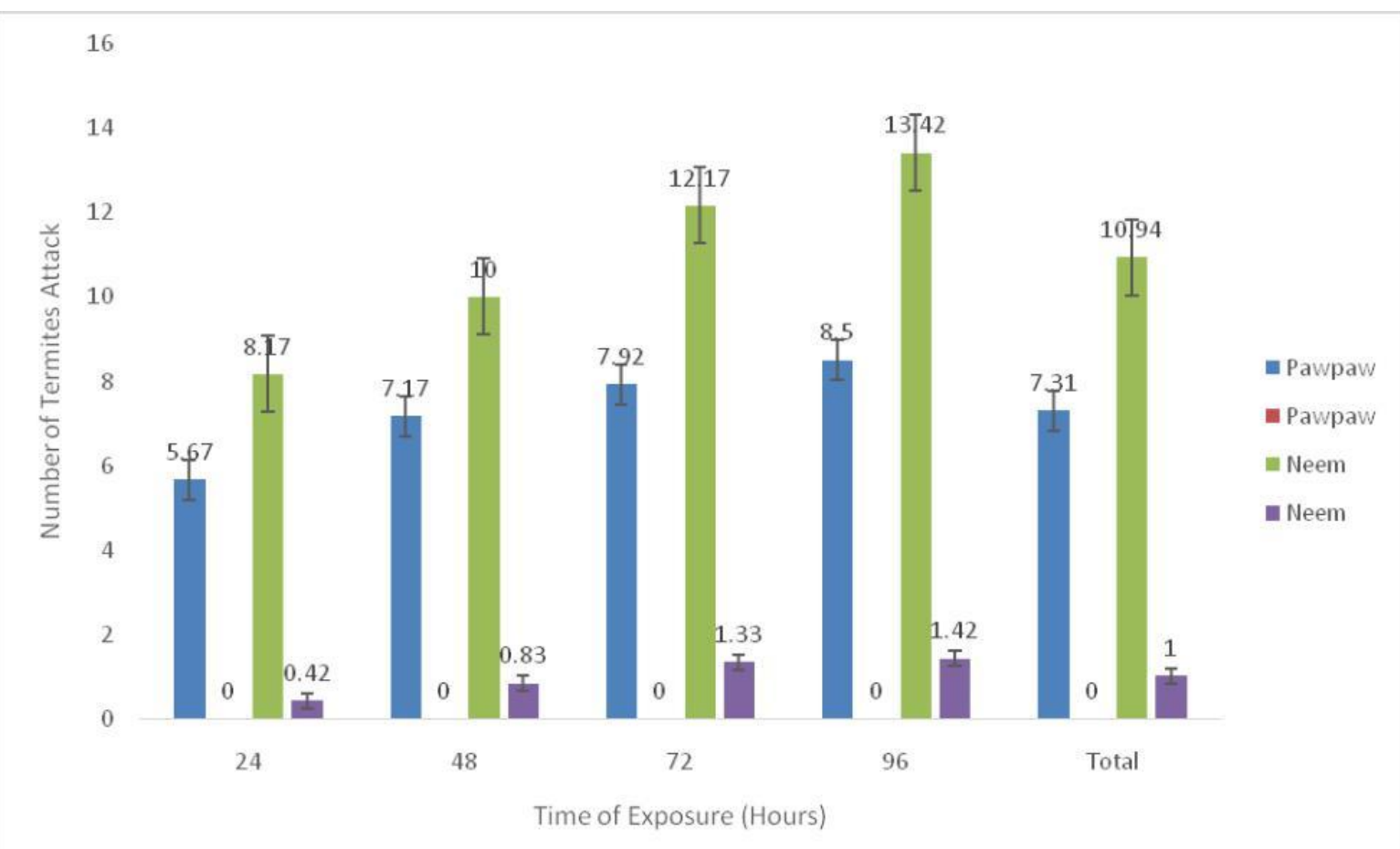

Figure 1: Efficacy of the extracts of the parts of the two plants against termite based on time of exposure

The result on the effect of methanolic and aqueous extracts of $C$. papaya and $A$. indica on the wood termite: $O$. badius, indicates that repellency of the termite from destroying the woods could be achieved depending on the extract used. The repellency result of the application of the extract from $A$. indica leaves and stems on the woods was similar to Serit et al. (1992) and Ahmed et al. (2016) who reported that neem oil of methanolic extract was more effective in repelling termites than the oil from the other plants and solvents extract.

Repellent activity manifested from the used of methanolic extracts of $C$. papaya and A. indica on the wood termites was effective because the methanol used during the extraction was able to induce more phytochemical constituents from the plants compared to the aqueous extract (Farkhanda et al., 2012). The woods treated with methanolic extract of $C$. papaya leaves were not attacked by the termites rather some of the termites were seen lying death on and around the wood. Noorshilawati et al. (2016) and Zahtamal et al. (2017) reported that $C$. papaya leaves extract has good termiticidal activities against termites. According to Osipitan and Oseyemi (2012), the repellency by the extracts could also lead to death of the termites, as the termites are starved of woody food material, while close contact of the termites to the treated woods in the termitarium would cause the termites become disoriented and die.

The termiticidal effect of the plant extract decreases with time which as the effect of the extract on the wood subsides the termites will attack the wood and cause damage. Also in the field, it was observed that the termites population in the termitaria used for the insertion of the woods treated with methanolic extracts of $C$. papaya and A. indica managed to continue inhabiting the termitaria and after 21 days of usage of the termitaria the termites exited the termitaria and was not rebuilt even after five days. This observation is similar to the observation from Ojianwuna et al. (2016) who in the toxicity and repellency of some plant extracts against termites in Abraka reported that the population of termites in termitaria in the field were managed with individual plant extracts and mixed proportions of extracts as the termitaria were not rebuilt after 30 days of post treatment.

Methanolic extracts of $C$. papaya (leaves and stem) and $A$. indica (leaves and stem) were highly effective with no termite attacked on $C$. pentandra, while the woods treated with aqueous extract of $C$. papaya and A. indica as similarly reported by Olufemi et al. (2011), were susceptible to termite 
attack. According to Nazeer et al. (2016) aqueous neem plant extract can caused mortality depending on its concentration.

\subsection{Conclusions}

The results from the study revealed that methanolic extracts of $C$. papaya and A. indica have potential to be used as biopesticides in controlling the infestation of $O$. badius on woods used in buildings in University of Uyo.

\section{References}

Ade-Ajayi, A. F., Hammuel, C., Ezeayanaso, C., Udiba, U. U., Anyim, B. and Olabani, O. (2011). Preliminary phytochemical and antimicrobial screening of Agave sisalana Perrine juice (waste). Journal of Environmental Chemistry and Ecotoxicology, 3(7), pp. 180-183.

Adegoke, A. T. and Bukola, C. (2009). Antibacterial Activity and Phytochemical Analysis of Leaf Extracts of Lasienthera africanum. African Journal of Biotechnolgy, pp. 077-080.

Adeyemi, M. M. H. (2010). The potential of secondary metabolites in plant material as deterents against insect pests: a review. African Journal Pure Applied Chemistry, 4(11), pp. 243-246.

Addisu, S., Mohammed, D. and Waktole, S. (2014). Efficacy of Botanical Extracts against Termites, Macrotermes spp., (Isoptera: Termitidae) Under Laboratory conditions. International Journal of Agricultural Research, 9, pp. 60-73.

Ahmed, N., Huma, Z., Haq, M. U., Rehman, S., Ullah, M. and Ahmed, S. (2016). Effect of different plant extracts on Termite species (Heterotermes indicola). Journal of Bioresource Management, 3(2), pp. 9-16.

Ajao, A. M., Oladimeji, Y. U., Oladipo, S. O. and Adepoju, S. A. (2018). Activity of MoundBuilding Macrotermes bellicosus (Isoptera: Termitidae) Around Kwara State University Campus Guinea Savannah Ecozone, Nigeria. Animal Research International, 15(1), pp. 2918-2925.

Akpan, A. U., Ojianwuna, C. C., Ubulom, P. M. E., Yaro, C. A. and Oboho, D. E. (2020). Effects of Physico-chemical parameters on the abundance and diversity of termites and other arthropods in termite mounds in Uyo, Akwa Ibom State, Nigeria. FUDMA Journal of Sciences, 4(2), pp. 92-100.

Arambewela, L. S. R., Arawwawala, L. D. A. and Ratnasooriya, W. D. (2005). Antidiabetic Activities of Aqueous and Ethanolic Extracts of Piper betle Leaves in Rat. Ethnopharmacology, pp. 239-245.

Arif, A., Muin, M., Larekeng, S. and Lestari, P. (2019). Survey and morphological identification of termites (Insecta: Isoptera) in Teaching Forest of Hasanuddin University, Indonesia. Conference Series: Earth and Environmental Science, pp. 1-10.

Biu, A., Yusufu, D. and Rabo, S. (2009). Phytochemical screening of Azadirachta indica (Neem) (Meliaceae) in Maiduguri, Nigeria. Bioscience Research Communications, 21(6), pp. 2821-28234.

Ce'spedes, C. L., Salazar, J. R., Ariza-Castolo, A., Yamaguchi, L., A'vila, J. G. and Aqueveque, P. (2014). Biopesticides from plants: Calceolaria integrifolia. International Environmental Research, 132, pp. 391-406. 
Chiu, C., Yeh, H., Li, P., Kuo, C., Tsai, M. and Li, H. (2018). Foraging Phenology of the Fungus-Growing Ternite Odontotermes formosanus (Blattodea: Termitidae). Environmental Entomology, 47(6), pp. 1509-1516.

Eggleton, P. (2007). Biological Letters. Science New. 171: 318

Evans, W. C. (2002). Trease and Evans' Pharmacognosy. $15^{\text {th }}$ Edition, Elsevier, A Division of Reed Elsevier India Pvt. Limited, India.

Farkhanda, M., Naz, N., Malik, S. A., Siddiqut, B. S., Syed, A. and Perwaiz, S. (2012). Chemical analysis and comparison of antitermitic activity of essential oils of neem (Azadirachta indica), vetiver (Vetiveria zizanioides) and mint (Mentha arvensis) against Heterotermes indicola (Wasmann) from Pakistan. Asian Journal Chemistry, 24(5), pp. 206972 .

Grimaldi, D. and Engel, M. (2005). Evolution of the insects. Cambridge University Press, $145 \mathrm{pp}$.

Hassan, B., Mankowski, M., Grant, K. and Sohail, A. (2017). Effects of heartwood extractives on symbiotic protozoan communities and mortality into termite species. International Biodeterioration and Biodegradation, 123, pp. 27-36.

Isman, M. B. (2017). Bridging the gap: Moving botanical insecticides from the laboratory to the farm. Industrial Crops Production, 110, pp. 10-14.

Nazeer, A., Huma, Z., Haq, M., Rehman, S., Ullah, M. and Ahmed, S. (2016). Effect of Different Plant Extracts on Termite Species (Heterotermisindicola). Journal of Bioresource Management, 3(2), pp. 9-16.

Nimmi, I., Jahan, I. A., Hossain, M. H., Burhan, M., Rana, M. S. and Haq, M. M. (2012). A comparative study on antioxidant properties of two Phyllanthus species growing in Bangladesh. Dhaka Univ Journal Pharmaceutical Science, 11(2), pp. 191-7.

Noorshilawati, A., Abdullah, S., Wan, H. and Mohamed, J. (2016). Termiticidal Activities of Carica papaya and Piper Betle methanolic and Aqueous Leaves Extracts against Coptotermes curvignathus. American Eurasian Journal of Agriculture and Environmental Science, 16(7), pp. 1383-1388.

Obinna, O., John, A. and Peter, O. O. (2013). The effect of extraction protocol on the phytochemical and antimicrobial activities of Lantana camara leaf extract found within a local environment. J. Basic Appl Sci. 3(1), pp. 5-10.

Obomanu, F., Ogbulu, K. and Edoris, S. (2016). Efficacy of Lepidagathis alopecuroides extracts as wood preservatives against Termites attack. Journal scientific research and reports, 12(6), pp. 1-7.

Ojianwuna, C. C., Olisedeme, P. and Ossai, S. L. (2016). The toxicity and repellency of some palnt extract applied as individual and mixed extracts against termites (Macrotermes bellicosus). Journal of Entomology and Zoology Studies, 4(1), pp. 406-418. 
Okere, C. I., Adaigbe, V. C., Aneni, T. I., Ogbebor, C. O., Aghayedo, C. O. and Akunne, C. E. (2021). Efficacy of two selected botanical extracts to protect wood from damage when exposed to termite attack. International Journal of Agriculture and Earth Science, 7(1), pp. $1-10$.

Olufemi, A., Gabriel, O., Bamidele, D. and Abubakar, U. (2011). Termiticidal Effect of Been extract on the wood of Khaya senegalensis. Research Journal of Forestry, 1-11pp.

Osipitan, A. A. and Oseyemi, A. E. (2012). Evaluation of the bio-insecticidal potential of some tropical plant extracts against termite (Termitidae: Isoptera) in Ogun State, Nigeria. Journal Entomology, 9(5), pp. 257-65.

Osipitan A. A., Jegede T. O., Adekanmbi D. I. and Ogunbanwo I. A. (2013). Assessment of Datura methel, local soap and garlic (Allium sativum) in the management of Termite (Termidae: Isoptera). Munis Entomology and Zoology, 8(1), pp. 407-414.

Oyedokun, J. C., Anikwe, F. A., Okelana, I. U. and Azeez, O. M. (2011). Pesticidal efficacy of three tropical herbal plant's leaf extracts against Macrotermes bellicosus, an emerging pest of Cocoa, Theobroma cocoa L. Journal of Biopesticides, 4(2), pp. 131-137.

Picker, M. (2004). Field Guide to Insects of South Africa. Cape Town: Struik Publishers. 56pp.

Prashant, T., Bimlesh, K., Mandeep, K., Gurpreet, K. and Harleen, K. (2011). Phytochemical screening and extraction: a review. Internationale Pharmaceutica Sciencia, 1(1), pp. 98-106.

Resh, V. and Carde, R. (2003). Encyclopedia of Insect. Academic Press New York. 23pp

Selase, A. G. and Getu, E. (2009). Evaluation of Some Botanical Plant Extracts Against Zabrotes Subfasciatus (Boheman) (Coleopteran: Bruchidae) In Stored Haricot Beans Under Laboratory Condition. African Journal Agricultural Research, 4, pp. 1073-1079.

Serit, M. I., Hagiwara, N., Kim, M., Yamamoto, T. and Takahashi, S. (1992). Meliaceae and Rutaceae limonoids as termite antifeedants evaluated using Reticulitermes speratus Kolbe (Isoptera: Rhinotermitidae). J. Chem Ecol. 18(4), pp. 593-603.

Silva, A. X., Jander, G., Samaniego, H., Ramsey, J. S. and Figueroa, C. C. (2012). Insecticide Resistance Mechanisms in the green peach aphid Myzus persicae (Hemiptera: Aphididae): A transcriptomic survey. PLoS ONE, 7(6): e36366.

Sotannde, O., Yager, O., Zira, D. and Usman, A. (2011). A termiticidal effect of been extract on wood of Khaya senegalensis. Research Journal of Forestry, 5(3), pp. 128-138.

Tolunay, A., Akyol, A. and Ozean, M. (2008). Usage of trees and forestry resources a house holds level. A study of AsagiYamrutas village from the west Mediterranean region of Turkey. Research Journal of Forestry, 2, pp. 1-14.

Ubulom, P. M. E., Akpan, A. U., Umohata, I. A. and Iboyo, E. A. (2020). Contact and Repellent effects of essential oils of Chromolaena odorata (L.) and Uvaria chamae (P.Beauv) against Macrotermes bellicosus (Smeathman). Journal of Biological Research and Biotechnology, 18(2), pp. 1154-1163. 
Ugbomeh, A. P. and Diboyesuku, A. T. (2019). Studies on termite infestation of buildings in Ase, a rural community in the Niger Delta of Nigeria. The Journal of Basic and Applied Zoology, 80(27), pp. 1-7.

Zahtamal, S., Ardiansyah, A., Titi, M., Soesilohadi, R., Setya, H. and Septi, M. (2017). Toxic Potential of Papaya (Carica papaya) leaves as Termicidal against Coptotermes curvignathus Holmgren. Agricultural, Chemical, Biological and Environmental Sciences, 7, pp. 43-45. 2021. Efficacy of the Methanolic and Aqueous Extracts of Carica Papaya and Azadirachta Indica against Wood Termite (Odontotermes Badius) in Uyo, Akwa Ibom State, Nigeria. Nigerian Journal of Environmental Sciences and Technology, 6(1), pp. 28-37. https://doi.org/10.36263/nijest.2022.01.0306 